\title{
Analysis of Work Design in Rubber Processing Plant
}

\author{
Dini Wahyuni ${ }^{1, *}$, Harmein Nasution ${ }^{1}$, Irwan Budiman ${ }^{2}$ and Khairini Wijaya ${ }^{1}$ \\ ${ }^{1}$ Department of Industrial Engineering, Faculty of Engineering, Universitas Sumatera Utara, Medan - Indonesia \\ ${ }^{2}$ Master Program of Industrial Engineering, Faculty of Engineering, Univers itas Sumatera Utara, Medan - Indonesia
}

\begin{abstract}
The work design illustrates how structured jobs, tasks, and roles are defined and modified and their impact on individuals, groups, and organizations. If the work is not designed well, the company must pay greater costs for workers' health, longer production processes or even penalties for not being able to meet the delivery schedule. This is visible to the condition in a rubber processing factory in North Sumatra. Work design aspects such as layouts, machinery and equipment, worker's physical working environment, work methods, and organizational policies have not been well-organized. Coagulum grinding machines into sheets are often damaged, resulting in 4 times the delay of product delivery in 2016, the presence of complaints of heat exposure submitted by workers, and workstation that has not been properly arranged is an indication of the need for work design. The research data will be collected through field observation, and distribution of questionnaires related aspects of work design. The result of the analys is depends on the respondent's answer from the distributed questionnaire regard ing the 6 aspects studied
\end{abstract}

\section{Introduction}

North Sumatra is one of the provinces in Indonesia which has a pretty extensive rubber plantations, totaling 395,017 hectares (sumutprov.go.id, 2014), or approximately $10.95 \%$ of all rubber plantations in Indonesia amounted to 3,606,245 Ha [1]. Production of processed rubber in Indonesia mostly RSS (Ribbed Smoked Sheet) with commodity SIR I to III (Standard Indonesian Rubber). On the initial observation in a rubber processing plant in North Sumatra, the design aspects of work such as layout, machinery and equipment, physical work environment, workers, work methods, and policy organizations have not wellordered. Coagulum grinder machine into a rubber sheet often suffered damage, so it happened 4 times the delay in delivery of the products in the year 2016, heat exposure complaints submitted workers, and workspaces that have not been well groomed is an indication of the need for an analysis of the work design done.

Work design discusses the technical aspects and the social aspect of the job. The technical aspects of the process, in the form of a collection of tasks that must be done and have the means in the form of technology, procedures, and equipment. Social aspects referring to the workers, that is related to the ability and attitude as well as the office that determines their roles and responsibilities $[2,3]$.

Work design illustrates how occupations, tasks, and roles are structured are set and modified as well as its impact on individuals, groups, and organizations. When the design work is not good, the company must pay health workers a larger, longer production process or company can't fill orders in a timely manner. $[4,5,6,7]$

Design improvement of work covering several aspects that should be improved as methods of work relating to machinery and equipment, the condition of the physical work environment, layouts, methods of work, organization, and policy workers, which need to be analyzed in advance in order to make known the shortcomings as well as its limitations.

\section{Method}

Figures and tables, as originals of good quality and well contrasted, are to be in their final form, ready for reproduction, pasted in the appropriate place in the text. Try to ensure that the size of the text in your figures is approximately the same size as the main text (10 point). Try to ensure that lines are no thinner than 0.25 point.

Design aspects of work that are to be analyzed are the layout, machinery and equipment, physical work environment, workers, work methods, and policy organizations. To get the actual condition of the object of research, using the 5 steps beginning from 10 steps Macroergonomics Analysis and Design (MEAD) [2]:

1) Examination of the environmental conditions and the organizational subsystem

2) Definition of the type of production system and setting performance expectations

3) Definition of unit operations and processes of work

4) Identification of variance

* Corresponding author: diniwahyuni2015@gmail.com 
5) The making of the matrix variance

To identify the problems of work design used questionnaire. In this study, the use of questionnaires is a staple in data collection. The purpose of the subject matter of making the questionnaire is to obtain information relevant to achieving the objectives of the research by way of asking a question to respondents are selected.

The closed questionnaire was compiled by following the format of the scale Likert. Likert type format is designed to allow respondents to answer in many levels of any granule questions or statements filed. As for the Likert, in the scale of importance respondents to a question in the question form is classified as follows:

1) Strongly agree, abbreviated with the symbol (SS).

2) Agree, abbreviated with the symbol (S)

3) Neutral, abbreviated with the symbol (N)

4) Disagree, abbreviated with the symbol (TS)

5) Strongly Disagree, abbreviated with the symbol (STS)

Testing the validity of the questionnaire done by using correlation Product Moment with the formula:

$r_{x y}=\frac{N \sum X Y-\left(\sum X\right)\left(\sum Y\right)}{\sqrt{\left[N \sum X^{2}-\left(\sum X\right)^{2}\right]\left[N \sum Y^{2}-\left(\sum Y\right)^{2}\right]}}$

Where: $r_{x y}$ is a coefficient of product moment, $\mathrm{X}$ is the number of answers the entire respondents per question, $\mathrm{Y}$ is the number of answers all the questions per respondent, and $\mathrm{N}$ is the number of respondents.

As for testing the validity of measures is as follows:

1. Establish a research hypothesis $\left(\mathrm{H}_{0}\right.$ : the questionnaire is an instrument that is valid and can be used in data collection; $\mathrm{H}_{1}$ : the questionnaire is not a valid instrument)

2. Assign the significance level $\alpha=0.05$

3. Determine the critical area of product moment with $\alpha=0.05$ and $\mathrm{N}=25$, namely $\mathrm{r}_{\text {tabel }}=0.381$

4. Calculate the product moment with the formula (1)

5. In conclusion, set accept $\mathrm{H}_{\mathrm{o}}$ if $\mathrm{r}_{\text {hitung }}>\mathrm{r}_{\text {tabel. }}$.
Questionnaire reliability testing done using Cronbach Alpha Coefficient in questions that have a score in the range of 1 to 5 . The formula used in calculating Cronbach Alpha coefficient: [8,9]

$r_{11}=\left[\frac{k}{(k-1)}\right]\left(\frac{\sum{\sigma_{b}}^{2}}{\sigma_{t}{ }^{2}}\right)$

Where: $r_{11}$ is the reliability of the instruments, $k$ is the number of questions in the grain instrument, $\sum \sigma_{b}{ }^{2}$ is the sum of the variance points questions, and $\sigma_{t}{ }^{2}$ is the variance in total.

Collecting data instrument reliability is said to have indicated high reliability or if test Alpha Cronbach a coefficient giving bigger than $r_{\text {kritis }}$

\section{Result and Discussion}

\subsection{The Actual Conditions of the Working System}

The spread of the open questionnaire aims to find out the condition of the working system in one of the rubber processing plant. Conditions that are known to want to include some aspects of compliance with research variables are used, namely: machinery and equipment, the condition of the physical work environment, layouts, methods of work, organization, and policy workers.

Details of the open questionnaire on question formulated based on aspects of the work design and include 3 initial steps on the methods which have been presented.

The entire answers of respondents against the grain of the open questionnaire questions are then summarized in a table and presented in the form of recapitulation answers accompanied by the percentage of each answer. Recap of the open questionnaire answers can be seen in Table 1.

Table 1. Recap Of The Open Questionnaire

\begin{tabular}{|c|c|c|c|}
\hline \multirow{2}{*}{ No. } & \multirow{2}{*}{ Questions } & \multicolumn{2}{|c|}{ Answers of the Respondents } \\
\hline & & Description & Percentage \\
\hline 1. & The difficulties workers in operating the machine. & $\begin{array}{l}\text { Care } \\
\text { Repair } \\
\text { Damage } \\
\text { Others }\end{array}$ & $\begin{array}{c}52 \% \\
32 \% \\
8 \% \\
8 \%\end{array}$ \\
\hline 2. & $\begin{array}{l}\text { The difficulties of workers in the use of the } \\
\text { equipment. }\end{array}$ & $\begin{array}{l}\text { Care } \\
\text { Storage } \\
\text { Others }\end{array}$ & $\begin{array}{l}40 \% \\
28 \% \\
32 \%\end{array}$ \\
\hline 3. & Environmental factors that impede the work. & $\begin{array}{l}\text { Hot } \\
\text { The Smell of } \\
\text { Dark } \\
\text { Others }\end{array}$ & $\begin{array}{l}40 \% \\
28 \% \\
20 \% \\
12 \%\end{array}$ \\
\hline 4. & The suitability of the layout work. & $\begin{array}{l}\text { Not set } \\
\text { Space limited } \\
\text { Traffic materials } \\
\text { Others }\end{array}$ & $\begin{array}{l}24 \% \\
20 \% \\
16 \% \\
40 \%\end{array}$ \\
\hline 5. & $\begin{array}{l}\text { The difficulties experienced by workers in } \\
\text { implementing the SOP or work instruction. }\end{array}$ & $\begin{array}{l}\text { Field conditions } \\
\text { Difficult to understand } \\
\text { Experience }\end{array}$ & $\begin{array}{l}40 \% \\
28 \% \\
28 \%\end{array}$ \\
\hline
\end{tabular}




\begin{tabular}{|c|l|l|c|}
\hline \multirow{2}{*}{ No. } & \multicolumn{2}{|c|}{ Questions } & \multicolumn{2}{c|}{ Answers of the Respondents } \\
\cline { 3 - 4 } & & \multicolumn{1}{c|}{ Description } & Percentage \\
\hline & & Others & $4 \%$ \\
\hline 6. & The company's efforts to maintain the safety and & APD & $52 \%$ \\
& occupational health. & Warning & $28 \%$ \\
& & Briefing & $20 \%$ \\
\hline 7. & The company's efforts to control the work. & Foreman & $64 \%$ \\
& & Asis. Analyst & $28 \%$ \\
\hline 8. & The difficulties in increasing workers' job skills. & Lab test & $8 \%$ \\
& & Experience & $52 \%$ \\
& & Job & $28 \%$ \\
\hline
\end{tabular}

\subsection{Identification of Variance}

The identification data of variance were conducted to classify variables existing problems to facilitate subsequent analysis process. Data variance is the problems that occur in the production process and obtained based on the recapitulation of the open questionnaire. Data is grouped in the tree variance factor of the problem can be seen in Figure 1.

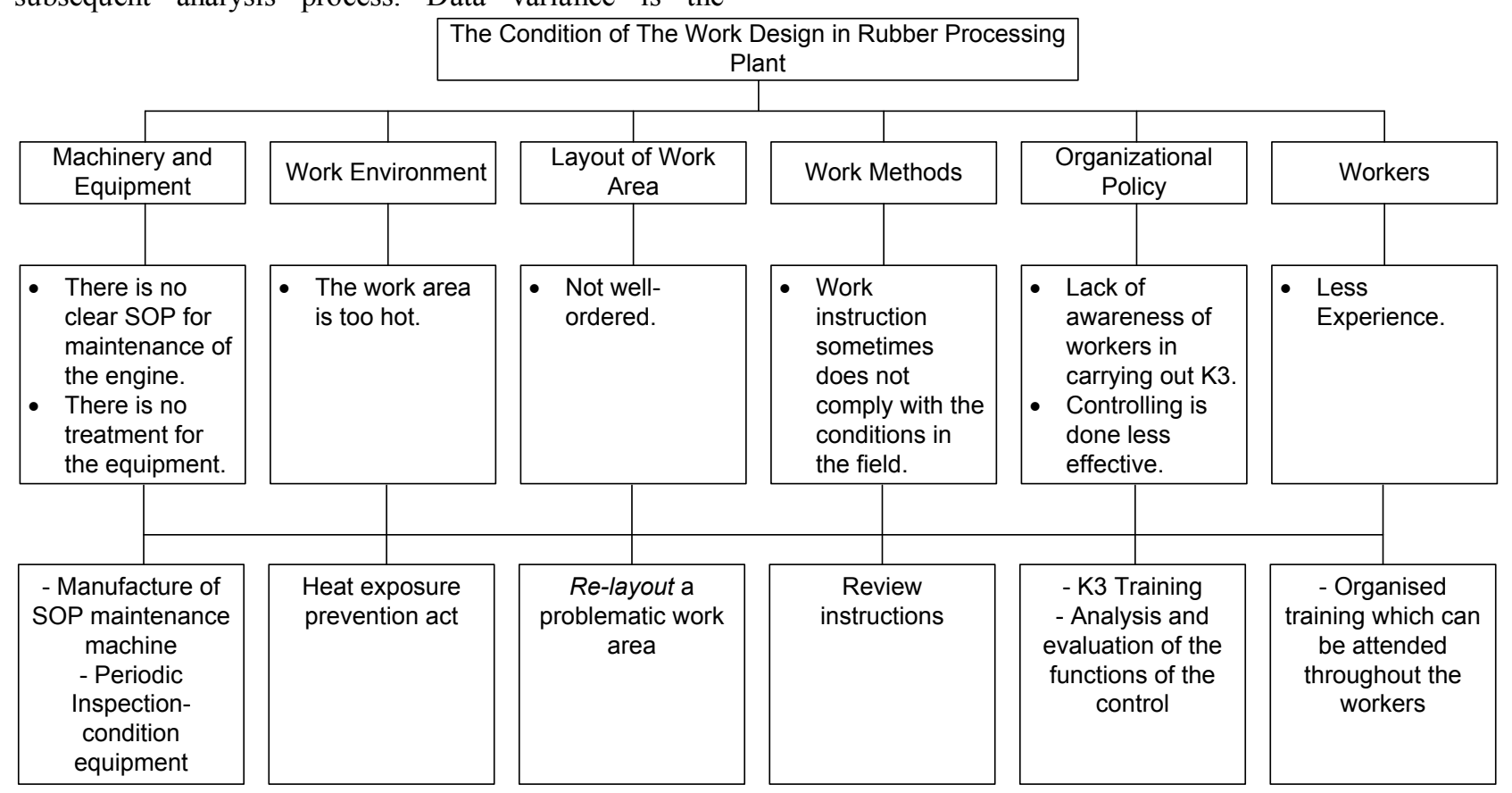

Fig. 1. Factor Tree Problems

\subsection{Preparation of Matrix Variances}

Data collection instruments used in the step of making matrix variance is a closed questionnaire. Matrix variances are arranged to illustrate the relationship between the variance. The process of preparing the matrix the variance using a Likert-scale measurement to look at the severity (severity) of a variance (Hendrick, 2002). The values in the matrix the variance is a score given to the respondent on a closed questionnaire which is then categorized according to their respective operations unit.

Dissemination of the questionnaire covered aims to know the perception of workers and assessment of the current system working conditions (current condition) as well as a comparison to achieve the desired system

working conditions (desired condition). The closed questionnaire consists of aspects that correspond to variables such as research on the questionnaire. The closed questionnaire is composed of 8 rounds each of the questions using the Likert scale. The answer to "strongly agree" interpreted with nominal 5, "Agrees" with nominal 4, "neutral" with nominal 3, "did not agree" with nominal 2, and the last "strongly disagree" with nominal 1.

Validity and reliability testing was done on the closed questionnaire and the questionnaire results obtained valid and reliability with the value of each 0.8279 and 0.9516 so it can be used as an instrument of research. Matrix variance presented in tables frequency corresponds to the number of answers that appear in the recapitulation of the questionnaire. Matrix variance can be seen in Table 2. The variance is the variance key- 
variance that significantly impact on the performance of the process of providing and/or interact with other variances so that the effect is affecting more than one operating unit.

Table 2. Matrix Variances

\begin{tabular}{|l|c|c|c|c|c|}
\hline \multirow{2}{*}{ Variances } & \multicolumn{5}{c|}{ Frequency of Answer } \\
\cline { 2 - 6 } & Strongly Disagree & Do Not Agree & Neutral & Agree & Strongly Agree \\
\hline There is no fixed schedule maintenance machine & 2 & 3 & 3 & 11 & 6 \\
\hline There is no maintenance for equipment & 2 & 5 & 6 & 7 & 4 \\
\hline Work area is too hot & 0 & 2 & 4 & 9 & 10 \\
\hline The layout is not set properly & 2 & 7 & 10 & 5 & 1 \\
\hline Instructions do not match field conditions & 1 & 6 & 8 & 7 & 3 \\
\hline Less awareness of maintaining work safety and health & 0 & 5 & 10 & 9 & 1 \\
\hline Controlling is done less effective & 4 & 5 & 7 & 9 & 0 \\
\hline Less experience & 8 & 3 & 4 & 7 & \\
\hline
\end{tabular}

From the table above, the specified key variance with Pareto approach (just a little bit that becomes the key variance), which has a total answer to agree and strongly agree the greatest. Analysis of work design has 2 variance key that will be completed first, namely a work area to overheat, and the absence of engine maintenance schedule periodically.

\section{References}

1. Indonesian Directorate of General Plantation, Statistics of General Plantation (2015)

2. H. W. Hendrik, Macro-ergonomics. Santa Monica: HFES. (2001)

3. N. Stanton, Handbook of Human Factor and Ergonomic Method. USA: CRC Press. (2005)

4. A. Rositaningrum. Analisa Implementasi Ergonomi Makro Terhadap Keuntungan Perusahaan (Studi Kasus : Merpati Maintenance Facility Juanda Surabaya). ITS: Surabaya (2014)
5. A.M. Grant, Giving Time, Time After Time: Work Design AndSustained Employee Participation In Corporate Volunteering. The Wharton School: University Of Pennsylvania. (2012)

6. S. Mayang,. Evaluasi Tracer Study Untuk Pembelajaran dengan Pendekatan Ergonomi Makro. Serang: Universitas Sultan Ageng Tirtayasa. (2013)

7. I. F. Mukti, Desain Perbaikan Lingkungan Kerja Guna Mereduksi Paparan Panas Kerja Operator di PT. XY. Medan: Universitas Sumatera Utara. (2013)

8. K. Parsons, Human Thermal Environments: The Effect of Hot, Moderate and Cold Environment on Human Health, Comfort and Performance. Second Edition. London: Taylor \& Francis. (2003)

9. A. Auliciems, S. V. Szokolay. Thermal Comfort. Brisband. 